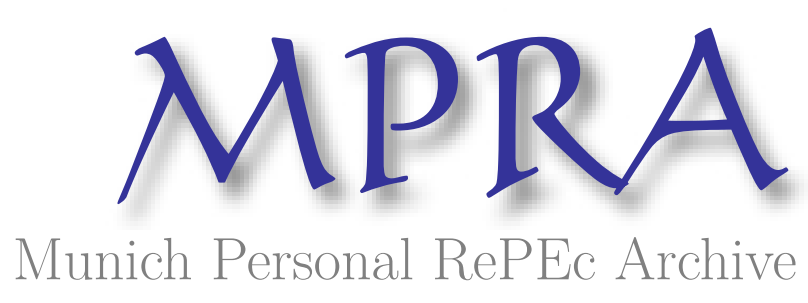

\title{
A Strategic Orientation Model for the Turkish Local e-Governments
}

\author{
Aykut, Arslan \\ Naval Training Center
}

March 2009

Online at https://mpra.ub.uni-muenchen.de/20704/

MPRA Paper No. 20704, posted 16 Feb 2010 22:39 UTC 


\title{
A STRATEGIC ORIENTATION MODEL FOR THE TURKISH LOCAL E- GOVERNMENTS
}

\author{
Aykut Arslan \\ Naval Training Command Center \\ Altınova, YALOVA \\ draykutarslan@gmail.com
}

\begin{abstract}
-Abstract -
Increased environmental uncertainty and complexity along with budget constraints requires public organizations to manage strategically as never before. The environments of public organizations have become increasingly turbulent and more firmly interconnected. During the past two decades, governments have innovated new management tools such as strategic planning, outsourcing, and performance measurement to deal with complex governance and networks to provide their public services. Meanwhile, the drive to implement e-government has resulted in the formulation of many e-government visions and strategies, driven by their own sets of political, economic, and social factors and requirements. With this regard, recent developments in e-service provision of Turkish Local e-Governments deserve empirical and well-structured research. Building on the recent literature, this study draws a strategic orientation framework and tests it by analyzing the contents of strategic documents of 114 Turkish Local e-Governments.
\end{abstract}

Key Words: Turkish Local e-Governments, e-Government Strategy, Strategic Orientation Model,

\section{JEL Classification: $0,01,018$}

\section{INTRODUCTION}

Local governments in particular have been innovative in economic development policy management and strategic planning to respond to rapid change in their environment and complexity in their governance. Discussions about the importance of strategic planning consistently emerge in literature on e-government, innovation, and information technology implementation (Fountain, 2001; Moon, 2002;

Kraemer and King, 2005). Strategic planning involves setting organizational goals and objectives and developing strategies for achieving them. An important purpose of strategic planning is also to determine the needs of customers and to develop approaches for meeting these needs in the most effective and efficient way. It blends futuristic thinking, objective analysis, and subjective evaluation of goals and priorities to chart a future course of action that will ensure the organization's vitality and effectiveness in the long run. An effective strategic plan has three integral components: (1) a desired outcome, (2) a strategy for achieving it, and (3)

Arslan, A. "A Strategic Orientation Model for1the Turkish Local e-Governments", 1st International Conference on eGovernment and eGovernance, published in Proceedings Book, March, 2009, Ankara. 
at least one measure for assessing whether or not the outcome is achieved (AIEA 2008). In other words, an effective approach to strategic planning should be structured not only to identify areas where new services are needed, or the level and quality of existing services needs to be enhanced, but should also be structured to evaluate the relative importance of these improvement initiatives. With regard to local e-Government this would mean finding out what core services should be provided for the residents and businesses of the municipality as the most useful.

This research analyzes the strategy documents of the Turkish municipal governments with populations over 50,000. The New Municipal Law of July 05, 2005 (Law number 5393) requires municipalities with populations over $50,000^{1}$ to develop strategic plans and tie them to budgets and performance measures.

Strategic planning has been used among the Turkish municipalities for four years now, but little is known about how it is used and the results obtained, particularly on e-government. Drawing from the recent literature of e-government, we formulate a strategy orientation framework. And in order to test this we seek answers for the following questions;

1. Do the strategy planning documents of the Turkish Local e-Governments deal with the e-services and on what level?

2. Do the strategy planning documents of the Turkish Local e-Governments constitute e-management issues such as intranets, extranets, and processes? 3. Do the strategy planning documents of the Turkish Local e-Governments constitute issues related to e-democracy and on what level?

4. Do the strategy planning documents of the Turkish Local e-Governments constitute the critical factors such as human resources, technology, funding, and multi-channel service delivery?

5. Do the strategy planning documents of the Turkish Local e-Governments constitute performance indicators regarding the e-services, e-management, and edemocracy?

\section{THEORETICAL FRAMEWORK}

Growing interest in the e-government concept in recent years (Huang et al. 2005) has stimulated discussions regarding what constitutes e-government. While some definitions of "e-government" refer mainly to the use of Internet and government websites or portals as the predominant theme (Pons, 2004; OECD, 2003), others use the term e-government to refer broadly to the adaptation of Information and Communication Technologies(ICT) to governmental use (Bretschneider, 2003; Koh and Prybutok, 2003). There are publications on e-government that measure the

\footnotetext{
1. The list of the municipalities can be downloaded from http://www.sp.gov.tr/documents/TUIKNUFUS22032008.xls.
}

Arslan, A. "A Strategic Orientation Model forthe Turkish Local e-Governments", 1st International Conference on eGovernment and eGovernance, published in Proceedings Book, March, 2009, Ankara. 
sophistication level of e-government on the basis of evaluating government websites (Siau and Long, 2005). Although this might be relevant to determining the usefulness of the websites and the information they provide, arguably this is not an adequate approach to assessing the level of maturity of the whole e-government approach. Although government websites, and/or portals, can be regarded as pivotal to an e-government approach, arguably there is a host of other activities that defines "e-government". It should be noted that the concept of e-government is "more than a technological phenomenon" (Grant and Chau, 2005). Issues of governance, information access, privacy, accountability, and public service amongst others also need to be considered. The push towards greater adoption of egovernment capabilities stems from the potential benefits promised by the concept of e-government (Grant and Chau, 2005). Some of the benefits commonly associated with the implementation of e-government range from greater efficiencies, the facilitation of internal administration, and improved levels of services to increased transparency, citizen empowerment and support for edemocracy (Schware and Deane, 2003; West, 2004). It is also believed that egovernment potentially enables the transformation of bureaucracy and public administration practices as we know them now (OECD, 2003; Fountain, 2001). Extracted from the related literature we argue that three key components are and should be central to strategic orientation. Those are:

E-services: Which services should be put online and on what extend?

E-management: To support and facilitate the e-services how should the organization be re-oriented?

E-democracy: How should e-government assuage democratic values in local context and on what extend?

Building a local e-government structure is a complex process that posits multiple coordination and resources from different actors. A web site might be an important medium of launching an e-government initiative but realizing interactive and collaborative e-services requires drastic changes in the management to support and facilitate those (Irani et al., 2007). During these periods of change some critical factors protrude and become the catalyst. We argue that the overall strategies of the local e-governments should comprise these critical factors to implement "e-s". Those are human sources, technology, funding, and multi-channel approaches (includes t-government, m-government, kiosks, phones, and the other traditional channels to cope up with the digital divide). Strategic planning draws a time frame and the scope of completion (rate) of the tasks in a given time frame which translates into performance indicators (The outcome) (Figure-1).

\subsection{E-services:}

Arslan, A. "A Strategic Orientation Model for3the Turkish Local e-Governments", 1st International Conference on eGovernment and eGovernance, published in Proceedings Book, March, 2009, Ankara. 
A local government has a different set of e-government objectives from a central government agency. Also different government agencies have different needs to support their specialized missions and objectives. Understanding what egovernment can offer and aligning it with organization's business objectives are an important but difficult task. Different studies tried to pinpoint features and service delivery concepts of e-governments such as Cooks' (2000)(cited in Koh and Prybutok, 2003) wish list through citizen input at the state level and Deshazo et al.'s (2001) (cited in Koh and Prybutok, 2003) 51 different e-government features at a municipal level. Albeit the claims that the most existing studies have recognized e-government somewhat arbitrary collection of functions and features, the Turkish local governments have dual responsibilities shaped either by the legislative mandates or by the expectation of their citizens. The new municipal law of 2004 (Law number 5393) posits more than 50 services within the local context. These should assist organizations in developing and designing specific web applications at a micro level. But intelligently organizing and effectively managing these services online requires a sound strategic plan that prescribes the integration of front-end web access capabilities with back-end systems. Available on-line "24h/7days" (West, 2004), e-services emphasize innovative forms of citizen involvement and offer services that demonstrate serious valuation of citizens as customer of administration. The strategic challenge is to deliver services to members of public along with dimensions such as quality, convenience, and cost. This includes business-related services such as license applications and interactive consulting. It also includes citizen-oriented services such as application for residency permits, weather and traffic information, and free e-mail services (Moon, 2002). Many contacts between the local government and citizens happen when specific services are wanted or needed. Examples include passport services, birth certificates, and entry into official databases (Fursich and Robins, 2002).

Several models have been proposed which outline stages of maturity as businesses embrace more of the capabilities of the web. Most e-commerce or e-business models outline three or four stages starting with net presence and often moving through to a stage incorporating elements such as a rich array of information, the full provision, and payment of services, or interaction with customers. Government departments often provide different types of services than commercial businesses, and frequently without payment. It is therefore probably inappropriate to extrapolate e-business models to the government sector. As Holden et al.(2003) referring Pardo (2000) argue that anyone can built a website, but digital government is beyond building a website. The vast literature of the e-government research map sees e-government as an incremental progression grounded on technological and organizational sophistication (Irani et al., 2005) as well as citizen orientation (Holden et al., 2003; Moon, 2002; Reddick 2004). Due to the very nature of the sophistication of the services offered via websites in terms of e-

Arslan, A. "A Strategic Orientation Model fortthe Turkish Local e-Governments", 1st International Conference on eGovernment and eGovernance, published in Proceedings Book, March, 2009, Ankara. 
services and e-democracy, and the related literature, we concluded that three normative stages may represent the progress of the local e-services: 1. Informative, 2. Interactive, and 3. Collaborative.

\subsubsection{Informative e-services}

These refer to information or advice that is published online and that is designed to help citizens or businesses efficiently carry out their daily activities. For instance, the links leading to a page covering weather, air quality or traffic information, upto-date food pricing, movie timetables, local maps, job information, were grouped into timely information for daily life.

\subsubsection{Interactive e-services}

With interactive e-services the term encompasses bidder applications, downloadable forms such as legal forms for consumers, various certificates, tax documents, and a variety of forms for application procedures, looking-up building permit processes, business licenses, and asynchronous e-mail communications, searchable consultative information for individuals or businesses, SMS messaging features. In some web sites, for instance, users can search information or documents by common subjects.

\subsubsection{Collaborative e-services}

Regarding the collaboration we refer the content that facilitates interaction between the web site and the user. This also indicates the highest level of e-service level. These services require more than a simple "click" to obtain information. Typically, the user has more control over content and the web site is more responsive to user input. Three major collaborative functions were identified in literature: 1) E-filing. For instance, individuals are able to check their tax status online on some web sites. Other examples include license application or renewal, registration of corporations and partnerships, online release of information about commodities, civil service status tracking, application for residency permit or renewal, record updates. 2) Epayment. In filing their taxes online or through SMS features, for example, taxpayers key-in and validate data themselves. Other examples include online payment systems for fines, utility bills, or permit fees. 3) Subscription/registration service. Some web sites require membership registration to receive a certain service. For instance, companies that wish to do business with the public sector do not need to search through newspapers or the web for information about bidding opportunities. Instead, they need only to register a single time in the areas in which they do business. Whenever a request is issued from a public agency, the system will automatically send e-mail to all the individuals or private companies registered

Arslan, A. "A Strategic Orientation Model forsthe Turkish Local e-Governments", 1st International Conference on eGovernment and eGovernance, published in Proceedings Book, March, 2009, Ankara. 
in that selected area, minimizing response time and providing an equal opportunity for all.

\subsection{E-management:}

Postulating accountability, transparency, efficiency (Kraemer and King, 2005), and renovated business processes (Irani et al., 2007), this perspective incorporates the behind-the-scene information systems supporting the management and administrative functions of public institutions, including data and information management, electronic records maintenance and cross-departmental flow of information (Sacowicz, 2001) via intranets or extranets. Effective usage of Information and Communication Technologies (ICT) demands a new change culture of organizations with staff teams focused on performance, customer services, and response to citizen input. In other words, these operations can be regarded as a Government-to-Government $(\mathrm{G} 2 \mathrm{G})$ interaction and the backbone of supporting the e-services. To support and facilitate the e-services they should be reoriented.

\subsection{E-democracy:}

One of the most controversial issues of e-government is the electronic version of democracy (Sacowicz, 2001). ICTs are used as the instruments to assist in setting agendas, establishing priorities, making important policies, and participating in their implementation in a deliberative way. E-democracy refers to activities that increase citizen involvement including virtual town meeting, open meeting, cyber campaigns, feedback polls, public surveys, and community forums (such as econsultation, e-voting, e-meetings, e-forums, user customization, volunteer opportunities, e-petitions) (Sacowicz, 2001). In short, if e-government is successfully implemented new empowered citizens may emerge (Le Porte et al. 2002; West 2004).

\subsection{Critical Factors}

To accomplish the aforementioned orientation framework the strategy planning should describe critical factors such as human resources, technology, funding, and multi-channel service delivery. Targets without these critical factors are considered to be ineffective and unrealistic (Siau and Long 2005).

\subsubsection{Human Resources}

Lack of appropriate human resources or lack of relevant skills of existing human resources may obstruct. Although, technology is important when implementing egovernment, people are more important when moving towards implementing e-

Arslan, A. "A Strategic Orientation Model fordthe Turkish Local e-Governments", 1st International Conference on eGovernment and eGovernance, published in Proceedings Book, March, 2009, Ankara. 
government systems (Heeks, 2006). E-government means change. Unwillingness or even resistance to change may obscure the entire project. A sound strategic planning should comprise the training needs of the staff in a given time frame just after the kick off of the project. The TURKSTAT research (2006) reports the low number of IT personnel and the lack of training as the main hurdles of egovernment adoption among the Turkish municipalities.

\subsubsection{Technology}

Technology is crucial to e-government. With the advent of ICTs such as the Internet, cable TVs, mobile phones, and their availability, it has become easier and even cheaper for the citizens to interact and enhance their relations with their governments. But providing efficient and effective services requires more than that. Web integrated planning support systems, content management systems, Management Information Systems (MIS), Geographic Information Systems (GIS), and Urban Information Systems (UIS) are the most advanced technologies that facilitate the realization of e-government initiatives.

\subsubsection{Funding}

Funding is important regarding the monitoring and measuring the results of projects to make smarter cost decisions. Without appropriate funding it will be difficult to realize any project. Efficient budget allocation is only available through a sound planning.

\subsubsection{Multi-channel Service Delivery}

Citizens/users expect a choice of channels. Citizens use a mix of channels according to the appropriateness of the channel, their expertise, and the social meaning of channels of communication and activities in various cultural contexts. The same user may also prefer to use different channels for various stages of interaction with government. The Internet is a channel suited for simple queries and accessing documents. When the area is unfamiliar or the issue is complex and blurred, users appreciated the web most as a way of making the face-to-face or telephone interaction more effective. Hence the electronic delivery of government services has to be designed so that the different delivery systems can be used in parallel or together.

\section{METHODOLOGY}

The terms such as local governments and municipalities or municipal local governments will be used interchangeably throughout the paper.

Arslan, A. "A Strategic Orientation Model for7the Turkish Local e-Governments", 1st International Conference on eGovernment and eGovernance, published in Proceedings Book, March, 2009, Ankara. 
The New Municipal Law of July 05, 2005 (Law number 5393) requires municipalities with populations over 50,000 to develop strategic plans and tie them to budgets and performance measures. Table 1 shows the distribution of these municipalities by their status and the availability of the strategic plans. When prepared, the strategic plans should be uploaded to the website of State Planning Organization (http://www.sp.gov.tr/spler.html). As of October 2008, the number of the municipalities which uploaded their strategy documents reached to 99. To assure that all the available planning documents are included in the sampling a thorough research was done in Google, Yahoo, and MSN search engines.

Additionally 15 more documents were summoned. Two of the documents from the previous group were taken out because both belonged to the subsidiaries of Greater Metropolitan Municipalities and were not representing overall strategy. In total, we got a sampling of 114 strategic plans. 13 out of 16 metropolitan municipalities ( $\%$ $81,25)$ prepared their strategic plans and constitute the most crowded group among the other local governments.

\section{Table 1: Status of Municipalities and Strategic Plans}

\begin{tabular}{|l|c|c|c|}
\hline Status of Municipalities & Number & Strategic Plans & $\mathbf{\%}$ \\
\hline Metropolitan & 16 & 13 & 81,25 \\
\hline Metropolitan District & 32 & 15 & 46,88 \\
\hline Provincial centers & 56 & 30 & 53,57 \\
\hline Districts & 139 & 56 & 40,29 \\
\hline Total & $\mathbf{2 4 3}$ & $\mathbf{1 1 4}$ & $\mathbf{4 6 , 9 1}$ \\
\hline
\end{tabular}

To analyze the strategic plans we used a computerized content-based analysis. It is "a systematic, replicable technique for compressing many words of text into fewer content categories based on explicit rules of coding" (Stemler, 2001). It often involves building and applying a "concept dictionary" or fixed vocabulary of terms on the basis of which words are extracted from the textual data for concording or statistical computation. The dictionary prepared for the analysis is available upon request.

The 115 strategic plans have been coded for language that, it is argued, indicates our three dimensional framework; e-services, e-management, and e-democracy orientation of the Turkish Local e-Governments. Additionally, critical factors such as human resources, technology, funding, and multi-channel service delivery were also evaluated. What's more, we analyzed the performance indicators regarding the e-services, e-management, and e-democracy orientation. An individual-word-count system methodology was applied to classify the texts by assigning words to prespecified semantically equivalent categories. Frequency counts or occurrences of words in each category were then analyzed to determine the relative concern given

Arslan, A. "A Strategic Orientation Model forgthe Turkish Local e-Governments", 1st International Conference on eGovernment and eGovernance, published in Proceedings Book, March, 2009, Ankara. 
each category by the text's author (Weber, 1990 as cited in Morris 1994).

Comparing almost-perfect reliability and cost effectiveness of simple computerized coding systems of this type against human coder's Morris (1994 by referring Rosenberg, Schnurr and Oxman, 1990) claims superiority.

\section{FINDINGS AND DISCUSSION}

Strategic planning has been used among the Turkish municipalities for four years now, but little is known about how it is used and the results obtained, particularly on e-government. It is important that a planning be specific in terms of both a time frame and the future state to assure the accomplishing of a project. Table 2 indicates the time frame of the Turkish Local Governments. The depth ranges form three years to twelve years. The frequent time frame is five-year frame $(\% 57,02)$.

Table 2: Time Frames of the Strategic Plans

\begin{tabular}{|l|c|l|}
\hline Time & Duration & $\mathbf{\%}$ \\
\hline Strategies with three-year Frame & 21 & 18,42 \\
\hline Four-year Frame & 22 & 19,30 \\
\hline Five-year Frame & 65 & 57,02 \\
\hline Six-year Frame & 3 & 2,63 \\
\hline Twelve-year Frame & 1 & 0,88 \\
\hline Unknown & 2 & 1,75 \\
\hline Total & $\mathbf{1 1 4}$ & $\mathbf{1 0 0}$ \\
\hline
\end{tabular}

\subsection{Findings of the Content Analysis and Discussions of the Research Questions}

The first question of our framework is whether the strategy planning documents of the Turkish Local e-Governments are dealing with the e-services and on what level (L1-Informative; L2-Interactive; L3-Collaborative). Table 3 gives the first part of our findings after the content analysis. Based on these results the highest rate of eservice related vocabulary $(\% 76,92)$ is observed in metropolitan strategic documents, whereas the lowest rate of the highest e-service (L3) objectives $(\%$ 15,38 ) are within the same documents; we may infer that these contradictive results indicate the targets reached. In other words, the metropolitan municipalities may have reached the targets already; so, pursuing this issue much further may not be required. As such, the rest of the municipalities (metropolitan districts, provincial centers, and districts) cover e-service targets relatively less ( $\%-13,59$ to $\%$ $30,25)$; but on the other hand their e-service level objectives are higher $(\%+11$ to $\%+18$ ). Another result derived from table 3 is about the approach of the depth of e-service levels. The strategies for levels are the highest on L1 (\% 73,21 to \%

Arslan, A. "A Strategic Orientation Model forgthe Turkish Local e-Governments", 1st International Conference on eGovernment and eGovernance, published in Proceedings Book, March, 2009, Ankara. 
$73,33)$ for provinces and districts referring informative objectives (detailed information on either the mayor or the municipal promotional activities).

Table 3: The Content Analysis of e-Service and the Level related Vocabulary in Strategic Plans

\begin{tabular}{|c|c|c|c|c|c|c|c|c|}
\hline \multicolumn{8}{|c|}{ Strategic Plans } \\
\hline Total & Metropolitan & $\mathbf{\%}$ & $\begin{array}{c}\text { M. } \\
\text { District }\end{array}$ & $\mathbf{\%}$ & $\begin{array}{c}\text { P. } \\
\text { Centers }\end{array}$ & $\mathbf{\%}$ & Districts & $\%$ \\
$\mathbf{1 1 4}$ & $\mathbf{1 3}$ & $\mathbf{1 1 , 4 0}$ & $\mathbf{1 5}$ & $\mathbf{1 3 , 1 6}$ & $\mathbf{3 0}$ & $\mathbf{2 6 , 3 2}$ & $\mathbf{5 6}$ & $\mathbf{4 9 , 1 2}$ \\
\hline E-serv. & 10 & $\mathbf{7 6 , 9 2}$ & 7 & 46,67 & 19 & 63,33 & 35 & 62,50 \\
\hline L1 & 8 & 61,54 & 8 & 53,33 & 22 & $\mathbf{7 3 , 3 3}$ & 41 & $\mathbf{7 3 , 2 1}$ \\
\hline L2 & 3 & 23,08 & 6 & 40,00 & 12 & 40,00 & 22 & 39,29 \\
\hline L3 & 2 & $\mathbf{1 5 , 3 8}$ & 4 & 26,67 & 8 & 26,67 & 19 & 33,93 \\
\hline
\end{tabular}

The second question is whether the strategy plans of the Turkish Local eGovernments constitute the e-management issues such as intranets, extranets, and processes. Table 4 gives the second part of our findings after the content analysis indicating higher percentages on e-management related targets, except metropolitan districts (The lowest \% 60). In terms of efficiency such as cost reduction, renewing administrative processes and other reform agendas, these outcomes may be intrinsically consistent. However, these may also be interpreted as intense organizational-focus, or from a deterministic perspective, signaling effective reorganization initiatives, required for supporting e-services.

Table 4: The Content Analysis of e-Management issues in the Strategic Plans

\begin{tabular}{|c|c|c|c|c|c|c|c|c|}
\hline \multicolumn{9}{|c|}{ Strategic Plans } \\
\hline Total & Metropolitan & $\%$ & $\begin{array}{c}\text { M. } \\
\text { District }\end{array}$ & $\%$ & $\begin{array}{c}\text { P. } \\
\text { Centers }\end{array}$ & $\%$ & Districts & $\%$ \\
\hline 114 & 13 & 11,40 & 15 & 13,16 & 30 & 26,32 & 56 & 49,12 \\
\hline E-Manage. & 11 & 84,62 & 9 & 60,00 & 24 & 80,00 & 42 & 75,00 \\
\hline
\end{tabular}

The third question of our framework is whether the strategy planning documents of the Turkish Local e-Governments are dealing with the e-democracy and on what level (L1-Informative; L2-Interactive; L3-Collaborative). Table 5 gives the third part of our findings after the content analysis. The very low level of e-democracy related vocabulary correlates the literature as stated earlier (Sacowicz, 2001). The highest rate $(\% 23,08)$ of e-democracy vocabulary in metropolitan municipalities' strategic plans may donate to objectives to further their pursuit of e-government agendas. As such, the lower percentages of other municipalities may indicate the direction of their efforts on e-service provisions rather than e-democracy. This

Arslan, A. "A Strategic Orientation Model foft the Turkish Local e-Governments", 1st International Conference on eGovernment and eGovernance, published in Proceedings Book, March, 2009, Ankara. 
trend was also reported earlier by Arslan (2007). All local governments targeted L1 the most, signaling initial stage of e-democracy.

Table 5: The Content Analysis of e-Democracy and the Level related Vocabulary in the Strategic Plans

\begin{tabular}{|c|c|c|c|c|c|c|c|c|}
\hline \multicolumn{8}{|c|}{ Strategic Plans } \\
\hline Total & Metropolitan & $\mathbf{\%}$ & $\begin{array}{c}\text { M. } \\
\text { District }\end{array}$ & $\mathbf{\%}$ & $\begin{array}{c}\text { P. } \\
\text { Centers }\end{array}$ & $\mathbf{\%}$ & Districts & $\%$ \\
$\mathbf{1 1 4}$ & $\mathbf{1 3}$ & $\mathbf{1 1 , 4 0}$ & $\mathbf{1 5}$ & $\mathbf{1 3 , 1 6}$ & $\mathbf{3 0}$ & $\mathbf{2 6 , 3 2}$ & $\mathbf{5 6}$ & $\mathbf{4 9 , 1 2}$ \\
\hline E-demo. & 3 & 23,08 & - & - & 1 & 3,33 & 3 & 5,36 \\
\hline L1 & 4 & $\mathbf{3 0 , 7 7}$ & $\mathbf{5}$ & $\mathbf{3 3 , 3 3}$ & $\mathbf{8}$ & $\mathbf{2 6 , 6 7}$ & $\mathbf{1 8}$ & $\mathbf{3 2 , 1 4}$ \\
\hline L2 & 3 & 23,08 & 3 & 20,00 & 6 & 20,00 & 15 & 26,79 \\
\hline L3 & 2 & $\mathbf{1 5 , 3 8}$ & 1 & 6,67 & 1 & 3,33 & 4 & 7,14 \\
\hline
\end{tabular}

The fourth question is how the strategy planning documents of the Turkish Local eGovernments treat the critical factors such as human resources, technology, funding, and multi-channel service delivery. Table 6 gives the fourth part of our findings after the content analysis. Except metropolitan districts the weigh of human related vocabulary is dispersed almost equally among the local governments. Contrary to this, the highest rate of metropolitan municipalities $(\%$ 61,54) may be translated into a technology-focused view. Being big in size means allocating more in budgets (Norris 1984). Metropolitan municipalities allocate more (\% 23,08) in terms of e-government funding in their strategy documents. As with the multichannel service delivery targets there seems to be almost no difference among the municipalities.

Table 6: The Content Analysis of the Critical Factor related Vocabulary Covered in the Strategic Plans

\begin{tabular}{|c|c|c|c|c|c|c|c|c|}
\hline \multicolumn{9}{|c|}{ Strategic Plans } \\
\hline Total & Metropolitan & $\mathbf{\%}$ & $\begin{array}{c}\text { M. } \\
\text { District }\end{array}$ & $\mathbf{\%}$ & $\begin{array}{c}\text { P. } \\
\text { Centers }\end{array}$ & $\mathbf{\%}$ & Districts & \% \\
\hline $\begin{array}{c}\text { Human } \\
\text { Resources }\end{array}$ & $\mathbf{1 3}$ & $\mathbf{1 1 , 4 0}$ & $\mathbf{1 5}$ & $\mathbf{1 3 , 1 6}$ & $\mathbf{3 0}$ & $\mathbf{2 6 , 3 2}$ & $\mathbf{5 6}$ & $\mathbf{4 9 , 1 2}$ \\
\hline Technology & 8 & 46,15 & 4 & 26,67 & 13 & 43,33 & 27 & 48,21 \\
\hline Funding & 3 & $\mathbf{6 1 , 5 4}$ & 4 & 26,67 & 10 & 33,33 & 25 & 44,64 \\
\hline $\begin{array}{c}\text { Multi- } \\
\text { channel }\end{array}$ & 4 & 30,77 & 3 & 20,00 & 10 & 33,33 & 19 & 33,93 \\
\hline
\end{tabular}

The fifth question was about the performance indicators regarding the e-services, emanagement, and e-democracy. Table 7 gives the fifth part of our findings after the Arslan, A. "A Strategic Orientation Model fof the Turkish Local e-Governments", 1st International Conference on eGovernment and eGovernance, published in Proceedings Book, March, 2009, Ankara. 
content analysis. Seifert and McLoughlin (2007) define processes, strategies, and performance measures as the most necessary requirements to achieve egovernment goals. We argue that strategic plans can indicate complex thinking, foresight, and deeper understanding of a given issue, all leading to a greater potential for success in implementation, however measured. This will assure and assist the municipalities to allocate their scarce resources in a profound way. This time, provinces and districts assigned performance indicators to their targets the most.

Table 7: The Content Analysis of the Performance Indicators regarding either e-Services or e-Democracy

\begin{tabular}{|c|c|c|c|c|c|c|c|c|}
\hline \multicolumn{8}{|c|}{ Strategic Plans } \\
\hline Total & Metropolitan & $\%$ & $\begin{array}{c}\text { M. } \\
\text { District }\end{array}$ & $\%$ & $\begin{array}{c}\text { P. } \\
\text { Centers }\end{array}$ & $\%$ & Districts & $\%$ \\
\hline $\begin{array}{l}\text { Perf. } \\
\text { Ind. }\end{array}$ & $\mathbf{1 3}$ & $\mathbf{1 1 , 4 0}$ & $\mathbf{1 5}$ & $\mathbf{1 3 , 1 6}$ & $\mathbf{3 0}$ & $\mathbf{2 6 , 3 2}$ & $\mathbf{5 6}$ & $\mathbf{4 9 , 1 2}$ \\
\hline
\end{tabular}

\section{CONCLUSION}

We argue that a successful strategic orientation should institute three "e"s; eservices, e-management, and e-democracy. To realize these targets certain critical factors ought to be appended as the catalysts. And at last, in a given time frame and gradually, the roadmap of the targets are supposed to be measured. We evaluated the strategy documents of the Turkish municipalities according to this framework. The overall results are highlighted in figure-1.

\section{Figure-1: The Strategic Orientation Framework and it's Constructs}

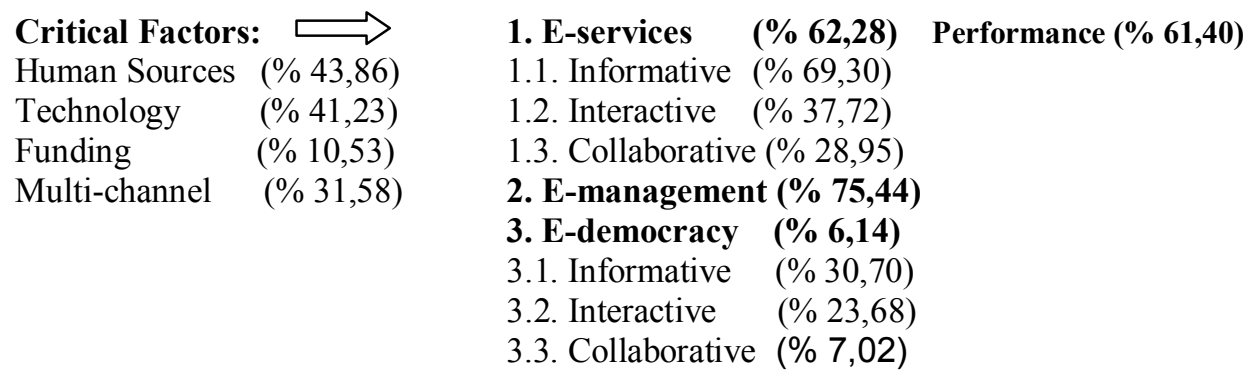

Out of 114 strategy documents (Figure-1), in general, 71 local governments (\% $62,28)$ included e-services in their strategies. 86 of those documents $(\% 75,44)$ covered e-management issues. When compared to e-services, this rate seems to be higher $(+\% 13,16)$ and posits a managerial approach. Our findings suggest that Arslan, A. "A Strategic Orientation Model fof the Turkish Local e-Governments", 1st International Conference on eGovernment and eGovernance, published in Proceedings Book, March, 2009, Ankara. 
most local authorities have in fact placed business processes, rather than technology, at the heart of their e-government strategies. Process improvements can take a number of forms: the flow of tasks can be undertaken more rapidly; tasks can be undertaken at lower cost; and the quality of output can be improved, for example by reducing the number of failed transaction which need to be reprocessed or by providing new channels to information and services. Process benefits can also accrue for staff, for example by facilitating flexible working (which may, for example, help to reduce staff turnover and thus recruitment costs).

There is a substantial gap to cover in terms of e-democracy by the Turkish Local Governments. The lowest rate $(\% 7,02)$ of e-democracy related vocabulary confirms this outcome.

Critical factors like funding $(\% 10,53)$ to allocate resources and to cover the costs and multi-channel service delivery strategies $(\% 31,58)$ are less covered.

The term e-service was almost entirely construed as a tax related issue in all of the strategies. Social activities such as application or enrollment for courses, look up modules of the libraries, reservations, or online ticket buying were not treated at all. This alone may be translated into managerial focus of the efforts.

Engaging in strategic planning can enhance local government leader's ability to position the municipality in achieving desired goals and outcomes particularly in terms of Local e-Governments. E-government initiatives have the potential to transform traditional bureaucracies. They inevitably involve changes in communication patterns, work practices, organizational structures, procedures, and processes enabled by the adoption and implementation of ICT (Forman, 2002). Over time, as government agencies and departments become intertwined in a mesh of electronic processes and activities, the characteristics of networked organizations will become more prevalent than the older forms of bureaucracy (Fountain, 2001). In order to anticipate the changes that may occur and to ensure the success of e-government initiatives, a well-thought-out e-government strategy needs to be developed and implemented. There is still a long way to go for the Turkish Local Governments regarding this issue.

\section{BIBLIOGRAPHY}

AIEA (2008), Strategic Planning Evaluation Guidelines: Strategic Plans and Action Plans, Eastern Washington University, http://www.ewu.edu/groups/ academicaffairs/IR/AIEA_Strategic_Plan_Evaluation_Guidelines.pdf.

Arslan, A. (2007), "Turkish Local e-Governments: a Longitudinal Study", The Electronic Journal of e-Government, Vol.5, No.2, pp $95-106$.

Arslan, A. "A Strategic Orientation Model fof Bhe Turkish Local e-Governments", 1st International Conference on eGovernment and eGovernance, published in Proceedings Book, March, 2009, Ankara. 
Bretschneider, S. (2003), "Information Technology, e-Government, and Institutional Change", Public Administration Review, Vol. 63, No. 6, pp. 738-741.

Forman, M. (2002), E-Government Strategy: Simplified Delivery of Services to Citizens. Executive Office of the President, Office of Management and Budget, Washington D.C..

Fountain, J.E. (2001), Building the Virtual State: Information Technology and Institutional Change. Brookings Institution, Washington D.C..

Fursich, E., \& Robins, M. B. (2002), “Africa.com: The self-representation of subSaharan nations on the World Wide Web", Critical Studies in Media Communications, Vol.19, No. 2, pp.190-211.

Grant, G. and Chau, D. (2005), "Developing a generic framework for e-government", Journal of Global Information Management, Vol. 13, No. 1, pp.1-30.

Heeks, R, (2006), Implementing and managing e-government: An international text. Thousand Oaks: Sage Publication.

Holden, S. H., Norris, D. F., \& Fletcher, P. D. (2003), "Electronic government at the local level. Progress to date and future issues", Public Performance and Management Review, Vol.26, No. 4, pp.325-344.

Huang, W., Siau, K. \& Wei, K.K. (2005), Electronic Government: Strategic and Implementations. Idea Publishing, Hershey.

Irani, Z., Love, P.E.D. and Montazemi, A. (2007), "E-government: past, present and future”, European Journal of Information Systems, Vol.16, pp.103-105.

Irani, Z., P.E.D Love, T. Elliman, S. Jones, \& M. Themistocleous (2005), "Evaluating e-government: learning from the experiences of two UK local authorities", Information Systems Journal, Vol.15, No.1, pp.61-82.

Koh, C.E. and Prybutok, V.R. (2003), "The three ring model and development of an instrument of measuring dimensions of e-government functions", Journal of Computer Information Systems, Vol. 43, No. 3, pp. 34-39.

Kraemer, K. L., and King, J. L. (2005), “Information Technology and Administrative Reform: Will the Time After E-Government Be Different?" http://www.si.umich.edu/ jlking/IJEGR-Final.pdf, [Accessed 02.12.2008].

Arslan, A. "A Strategic Orientation Model folt the Turkish Local e-Governments", 1st International Conference on eGovernment and eGovernance, published in Proceedings Book, March, 2009, Ankara. 
Le Porte, T.M., de Jong, W.M., and Demchack, C.C. (2002), "Public Organizations on the World Wide Web; empirical correlates of Administrative Openness", Administration and Society, Vol.34, No.4, pp.416-46.

Moon, M.J. (2002), "The evolution of e-government among municipalities: Rhetoric or reality?", Public Administration Review, Vol.62, No.4, pp. 424-433.

Morris, Rebecca (1994), "Computerized content analysis in management research: a demonstration of advantages \& limitations", Journal of Management, Vol.20, No. 4, 903-931.

Norris F. D. (1984), "Computers and Small Local Governments: Uses and Users", Public Administration Review, Vol. 44, No.1, pp.70-78.

OECD (2003), "The case for e-government: Excerpts from the OECD report "The eGovernment Imperative", OECD Journal on Budgeting, Vol.52, No.1, pp. 62-96.

Pons, A. (2004), "E-government for Arab countries", Journal of Global Information Management, Vol. 7, No. 1, pp. 30-46.

Reddick, C.G. (2004), "Empirical Models of E-Government Growth in Local Governments", E-service Journal, Vol.3, No. 2, pp.59-84.

Sacowicz, M (2001), "How to Evaluate e-Government? Different Methodologies and Methods", http://unpan1.un.org/intradoc/groups/public/documents/ NISPAcee/UNPAN009486.pdf, [Accessed 02.12.2008].

Schware, R. and Deane, A. (2003), "Deploying e-government programs: The strategic importance of 'I' before 'e", Info, Vol. 5, No. 4, pp.10-19.

Seifert, J.W. and McLoughlin, G.J. (2007), "State E-government strategies: Identifying best practices and applications", Congressional Research Service report \# RL34104, http://www.fas.org/sgp/ crs/secrecy/RL34104.pdf, [Accessed 20.04.2008].

Siau, K. and Long, Y. (2005), "Synthesizing e-Government Stage Models - a Metasynthesis Based on Meta-Ethnography Approach", Industrial Management \& Data Systems, Vol.105, No. 4, pp.443-458.

Stemler, Steve (2001), "An overview of content analysis", Practical Assessment, Research \& Evaluation, Vol.7, No.17.

TurkStat (2006), "Municipal Web Services Research, 2005”, TurkStat News Bulletin, Number 19, January 31, 2006, http://www.die.gov.tr/ENGLISH/

SONIST/DISTICIST/k_310106.xls, [Accessed 08.03.2006]

Arslan, A. "A Strategic Orientation Model fof the Turkish Local e-Governments", 1st International Conference on eGovernment and eGovernance, published in Proceedings Book, March, 2009, Ankara. 
West, D.M. (2004), "E-government and the transformation of service delivery and citizen attitudes", Public Administration Review, Vol. 64, No. 1, pp. 15-27.

Arslan, A. "A Strategic Orientation Model fof the Turkish Local e-Governments", 1st International Conference on eGovernment and eGovernance, published in Proceedings Book, March, 2009, Ankara. 